\title{
The International Code for Ships Operating in Polar Waters: Finalization, Adoption and Law of the Sea Implications
}

\author{
Øystein Jensen ${ }^{\star}$, \\ Fridtjof Nansen Institute, Lysaker, Norway
}

\begin{abstract}
The most recent instrument specifically designed to make navigation in polar waters safer and more environmentally friendly is the International Maritime Organization's long-awaited "International Code for Ships Operating in Polar Waters" - the Polar Code. This article first briefly examines the legislative history of the Code, with emphasis on the final and consolidating phase of development. Second, an account is provided of the main contents of the Code as regards its regulations on safety measures and pollution prevention. Finally, the analysis places the new framework in the broader context of international law, including an examination of the Polar Code's relationship to specific provisions and legislative arrangements of the United Nations Convention on the Law of the Sea.
\end{abstract}

Keywords: Polar Code; navigation; Arctic; Antarctic; IMO

Received: November 2015; Accepted: April 2016; Published: May 2016

\section{Introduction}

In recent years the international community has taken considerable steps in the direction of new legal tools to address safety and environmental risks associated with polar navigation. In November 2014, the Marine Safety Committee (MSC) of the International Maritime Organization (IMO) adopted the maritime safety provisions of the International Code for Ships Operating in Polar Waters (henceforth: the Polar Code $)^{1}$ as well as amendments ${ }^{2}$ to the International Convention for the Safety of Life at Sea, 1974, as amended (SOLAS). ${ }^{3}$ In May 2015, IMO's Marine Environment Protection Committee (MEPC) followed suit, and adopted the environmental protection provisions of the Polar Code and a series of amendments to the 1973 International Convention for the Prevention of Pollution from Ships, as modified by

${ }^{\star}$ Correspondence to: Øystein Jensen, Fridtjof Nansen Institute, P.O. Box 326, 1326 Lysaker, Norway. Email: oyj@fni.no 
the Protocol of 1978 (MARPOL), ${ }^{4}$ to ensure that the mandatory provisions become legally binding. In all likelihood, the mandatory safety and environmental provisions of the Polar Code will thus soon be incorporated in legally binding treaties.

The Polar Code is a technical instrument, and an attractive object of study for those interested in details concerning requirements for matters such as ship construction, rescue equipment, and training requirements for crew on board ships trading in Arctic and Antarctic waters. However, the new regulations also merit analysis in the broader context of international law - not least, the relationship of the Polar Code to the international legal framework pertaining to navigation in all oceans included in the United Nations Convention on the Law of the Sea (LOS Convention). ${ }^{5}$

This article examines the new Polar Code in the context of general aspects of international law and the LOS Convention, starting with the drafting history of the Polar Code. Emphasis is placed on the final consolidation phase of development, when regulating polar navigation emerged as a renewed item on the IMO agenda and the aim was to make legally binding international law, not merely recommendations. Next, the main contents of the Polar Code are reviewed, focusing on the Code's regulations on safety measures and pollution prevention. Finally, the following implications for international law are analyzed: treaty interpretation in light of the legislative techniques utilized in the Polar Code; the prominence of the regulations of the Polar Code in the context of the LOS Convention's concept of "generally accepted international rules and standards"; and the relationship of the Polar Code to Article 234 of the LOS Convention.

\section{Legal development}

The legislative history of the Polar Code can be roughly divided into three stages of development. The first period, 1991-2002, saw initiatives for making navigation in polar ice-covered waters safer and more environmentally friendly brought to the agenda of the IMO for the first time, culminating in the 2002 guidelines for ships operating in Arctic ice-covered waters. The second stage of development, 2002-2009, was characterized by initiatives to expand the guidelines to include Antarctic waters as well. In the final stage of development, 2009-2015, the process of transforming the regulations from mere guidelines to binding legal obligations re-emerged on the IMO agenda.

Work on the Polar Code has been coordinated by the IMO Sub-Committee on Ship Design and Equipment (DE). Following IMO's restructuring of its subcommittees, the Sub-Committee on Ship Design and Construction (SDC) took over this responsibility in 2014. Various working groups have had responsibility for proceeding with the work, with correspondence groups continuing between sessions. The parent bodies have been MSC, with respect to safety provisions, and MEPC, with respect to environmental provisions. The following review presents some key aspects of more than 25 years of this development. 


\subsection{1-2002}

Initiatives for a new legal regime for polar navigation were triggered by the Exxon Valdez disaster off the coast of Alaska in 1989. During the 59th session of the MSC in 1991, Germany proposed inclusion of the following rule in SOLAS:

Ships intended for service in Polar Waters should have suitable ice strengthening for Polar conditions in accordance with the rules of a recognized classification society. ${ }^{6}$

MSC referred the matter to its DE sub-committee, which allowed an informal Outside Working Group (OWG) to develop proposed guidance regarding technical concerns for ships operating in polar waters. ${ }^{7}$ The work resulted in a draft, "International Code of Safety for Ships in Polar Waters," submitted to DE 41 in $1998 .^{8}$ The draft code aimed to ensure that all ship operations in polar waters would meet "internationally acceptable standards." 9

Since DE 41, however, many States and stakeholders had made submissions to the draft code. ${ }^{10}$ A significant set of changes was subsequently introduced by MSC. For instance, MSC directed that Antarctic waters were to be excluded from the Code's geographical application. ${ }^{11}$ Also any provision in the Code inconsistent with international law should be removed. ${ }^{12}$ A revised draft of the Code, "Guidelines for Ships Operating in Arctic Polar Waters," was developed by a correspondence group established by DE $41 .{ }^{13}$

A new version of the Code, now titled "Guidelines for ships operating in Arctic ice-covered waters," 14 was prepared, and DE 44 agreed in principle to the draft guidelines. ${ }^{15}$ With some modifications agreed in plenary, MEPC 48 (October 2002), ${ }^{16}$ and MSC 76, (December 2002), subsequently approved the "Guidelines for Ships Operating in Arctic Ice-covered Waters."17

\subsection{2-2009}

Two years after adoption, the Arctic Shipping Guidelines re-emerged on the IMO agenda. In view of the increase in shipping activities in Antarctic waters, the Antarctic Treaty Consultative Meeting (ATCM) requested ${ }^{18}$ that the IMO should amend the guidelines to make them applicable to ships operating in ice-covered waters in the Antarctic as well. ${ }^{19}$

MSC 79 (2004) considered ATCM's request. ${ }^{20}$ The damage, capsize and sinking of $M V$ Explorer while operating in Antarctic waters in 2007 gave further momentum to the initiative, and the correspondence group working on the Code between DE sessions considered several issues raised by this event. ${ }^{21}$ Moreover, the US now supported revisions to the Code that would broaden application of the guidelines to ships operating in Antarctic waters. Further, in January 2009, the US submitted proposals to MSC that would recast the guidelines as mandatory requirements. ${ }^{22}$

DE 52 agreed to give its working group the task of finalizing the guidelines, and asked the group consider expanding the agenda to include the US proposals on mandatory requirements mentioned above. ${ }^{23} \mathrm{~A}$ two-way approach was proposed. First, the guidelines should be formulated in such a way that they could serve as a 
basis for future development. Second, a new item, on developing a mandatory instrument for ships operating in polar waters, should be included on the agenda. ${ }^{24}$

DE 52 instructed the working group first to finalize the revised guidelines and second to prepare a justification for a new agenda item: "Development of a Code for ships operating in polar waters." 25 A draft resolution on "Guidelines for ships operating in polar waters" - Resolution A.1024(26) - was approved by MSC $86^{26}$ and MEPC $59 .{ }^{27}$ The new guidelines were subsequently adopted by the 26 th session of the IMO Assembly on 2 December 2009.

\subsection{9-2015}

Although the new guidelines were first finalized and adopted in December 2009, initiatives to develop mandatory requirements had emerged earlier that year. The first US proposal was submitted in January; a few months later Denmark, Norway and the US formally proposed that appropriate sub-committees should start developing mandatory requirements for ships operating in the polar regions. ${ }^{28}$ A new high-priority item on "Development of a mandatory Code for ships operating in polar waters" was approved by MSC in May 2009. ${ }^{29}$ Target completion date was $2012 .^{30}$

Work on the new Polar Code continued at DE 55 and 56, in which the working group further developed technical aspects of the draft. Important procedural imperatives also came under discussion, notably options for making a future Polar Code mandatory. Subsequently, DE did two things. First, it urged the parent bodies - MEPC and MSC - to prioritize discussions on how to make the Code formally binding. ${ }^{31}$ Second, it requested that the IMO Secretariat submit a document to MEPC 62 in which the Legal Office explored options for making the Code's provisions mandatory. ${ }^{32}$

The Legal Office outlined three options. The first option entailed amending SOLAS by adding a new chapter that incorporated the entire Polar Code by reference in the regulations and subject to the tacit amendment procedures of that convention. ${ }^{33}$ The second option was to amend both SOLAS and MARPOL by adding a new chapter to SOLAS that mandated the parts of the Polar Code relating to ship safety, as well as by amending one or more Annexes of MARPOL that addressed the environmental protection aspects of the Code. The third option was to develop an entirely new stand-alone convention on ships operating in polar waters with the Code either incorporated by reference and subject to the amendment requirements of the new convention, or attached as an annex to the new convention.

MEPC 63 decided to follow the second option. Accordingly, all relevant existing instruments were to be amended to mandate the associated provisions of the Code. ${ }^{34}$ In November 2012, MSC 91 also proposed following the second option. The Code would thus comprise a general part, a part on safety measures, and a part on pollution prevention measures. It would be adopted under the relevant applicable IMO instruments; specific maritime safety and pollution prevention requirements could be amended independently. ${ }^{35}$ 
DE 57, in March 2013, made significant progress in further developing the Polar Code. A draft chapter on environmental protection for consideration by MEPC 65 was finalized. ${ }^{36}$ In principle, agreement was also reached on definitions of the categories of ships covered by the Code. It was also agreed that all ships operating in polar waters be required to carry a "Polar Ship Certificate" and a "Polar Water Operation Manual." 37 Taking into account the decisions reached by MEPC 63 and MSC 91 mentioned above, DE also agreed that parts of the Code would be adopted by separate MSC and MEPC resolutions. ${ }^{38}$ The aim was to finalize the Code in 2014.

Following a restructuring of IMO sub-committees, in 2014 DE became the "Sub-Committee on Ship Design and Construction" (SDC). At its first session in January 2014 -at the time when the MVAkademik Shokalskiy was trapped in thick ice in Commonwealth Bay in Antarctica - SDC continued its work on the Polar Code. SDC agreed, in principle, to the draft "International Code for ships operating in polar waters (Polar Code)," for submission to MEPC 66 and MSC 93, with a view to adoption. There was also agreement on the text of the associated SOLAS and MARPOL amendments. ${ }^{39}$ The draft Code now included measures covering safety (part I-A) and pollution prevention (part II-A), as well as recommendatory provisions on both (parts I-B and II-B). ${ }^{40}$

SDC drafted a new "Chapter XIV" of SOLAS to make the safety part of the Code (Introduction and part I-A) mandatory. ${ }^{41}$ Proposed draft amendments to MARPOL were also developed, to make the Introduction and part II-A mandatory under different annexes to that convention. ${ }^{42}$ MSC 93 and MEPC 66 were subsequently invited to approve the drafts, subject to deciding on the text remaining throughout the Code, and with a view to final adoption at MSC 94 and MEPC 67.

MSC 94, held in London 17-21 November 2014, adopted the safety-related provisions of the Polar Code ${ }^{43}$ and amendments to SOLAS. ${ }^{44}$ MEPC 68 (London, 11-15 May 2015) adopted the environmental regulations of the Code ${ }^{45}$ and associated amendments to MARPOL to make the Code mandatory. ${ }^{46} \mathrm{~A}$ historic milestone in the development of international shipping law had been reached.

\section{Procedural and substantive aspects}

There are now four new IMO resolutions in place. First, the text of the Polar Code "International Code for Ships Operating in Polar Waters (Polar Code)" - is included in Resolution MSC.385(94) of 21 November 2014, whereby MSC adopted the safety-related provisions of the Introduction, and the whole of parts I-A and I-B of the Polar Code. Second, the final text of the Code is also included in Resolution MEPC.264(68) of 15 May 2015, whereby MEPC adopted the Introduction as related to environmental protection, and the whole of parts II-A and II-B of the Polar Code. Third, there are the amendments to SOLAS - "Amendments to the International Convention for the Safety of Life at Sea, 1974, as amended" - included in Resolution MSC.386(94), and adopted by MSC on 21 November 2014. Fourth, there are the rules for amending MARPOL - "Amendments to the Annex of the Protocol of 1978 
Relating to the International Convention for the Prevention of Pollution from Ships, 1973" - included in Resolution MEPC.265(68), and adopted by MEPC on 15 May 2015.

We focus first on the latter two of these instruments, as they will make Parts I-A and II-A of the Polar Code legally binding in the sense of implementing the regulations as part of SOLAS and MARPOL. The safety provisions of the Polar Code are now set to become a new "Chapter XIV - Safety Measures for Ships Operating in Polar Waters" under SOLAS, to enter into force on 1 January 2017. ${ }^{47}$ The environmental provisions of the Polar Code (i.e. Part II-A) are to be included in MARPOL through amendments in Annexes I, II, IV and V, also with entry into force 1 January $2017 .^{48}$

\subsection{SOLAS Chapter XIV}

According to Regulation 3, paragraph 1, of SOLAS Chapter XIV, ships to which the chapter applies "shall comply with the requirements of the safety-related provision of the Introduction and with part I-A of the Polar Code." However, which ships do these new safety rules apply to, and in which waters?

In terms of geographical application, "polar waters" are defined in Regulation 1, paragraph 4, as "Arctic waters and/or the Antarctic area." While the "Antarctic area" is simply defined as the "sea area south of latitude $60^{\circ} \mathrm{S}$," "Arctic waters" required a more detailed definition. Intended for illustrative purposes only, a useful figure showing the maximum extent of Arctic waters application is included in the "Introduction" to the Polar Code (see Figures 1 and 2). All sea areas north of latitude $60^{\circ} \mathrm{N}$ are covered by the area of the Code's application, except for those where ice is not present. Here it should be noted that the Polar Code applies to the sea areas adjacent to Svalbard, Norway's remote Arctic archipelago, visited by many cruise liners every year.

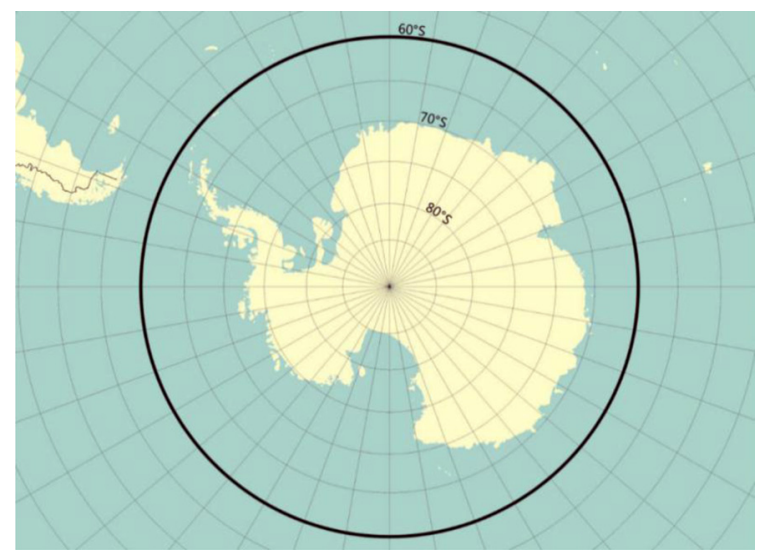

Figure 1. Geographical application of the Polar Code in the Antarctic, as defined in SOLAS regulations XIV/1.2.

Source: IMO Doc. MEPC 68/21/Add.1, Annex 10. 


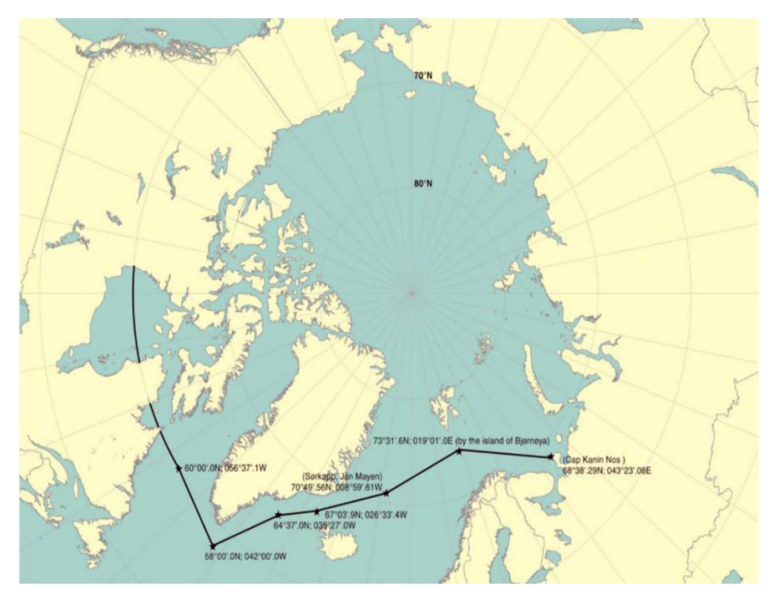

Figure 2. Geographical application of the Polar Code in the Arctic, as defined in SOLAS regulations XIV/1.3.

Source: IMO Doc. MEPC 68/21/Add.1, Annex 10.

As regards ship types, Regulation 2, paragraph 1, provides that (unless expressly provided otherwise) Chapter XIV shall apply to

ships operating in polar waters, certified in accordance with chapter I [of SOLAS].

Accordingly, not all ships are subject to the regulations. First, SOLAS, as the main rule, applies only to ships on "international voyages." 49 An "international voyage" under SOLAS is defined as a "voyage from a country to which the present Convention applies to a port outside such country, or conversely." issue is whether vessels operating solely in the waters off Antarctica are excluded from the area of application. The context indicates that whether or not a ship actually calls at a port in another country is not decisive - more important is that such vessels operate "in polar waters." This is supported by the fact that non-international trading voyages in the Antarctic maritime area are similar in nature to "international voyages" and should therefore be considered "international voyages." Importantly too, the purpose of the Polar Code and SOLAS - stated in the preamble of the Code - is to increase the safety of ships' operations and mitigate negative impacts on passengers, crew and the environment in polar waters. Obviously, perils of the sea do not distinguish between ships engaged in international or non-international voyages. Applying the new provisions to "non-international voyages" would be an important response to the urgent need to enhance the safety of ships and people navigating off Antarctica.

Unless expressly provided for, Regulation 3 of Chapter I also determines that the Convention does not apply to ships of war and troopships, cargo ships of less than 500 gross tons, ships not propelled by mechanical means, wooden ships of primitive build, pleasure yachts not engaged in trade, and fishing vessels.

Chapter XIV provides additional exceptions. First, it follows from Regulation 2, paragraph 2, that ships constructed before 1 January 2017 shall merely meet "the 
relevant requirements of the Polar Code by the first intermediate or renewal survey, whichever occurs first, after 1 January 2018." It is not obvious how to construe the meaning of the term "relevant requirements," but, apparently, the Code in toto applies only to new ships, i.e. ships constructed after 1 January 2017.

Second, Regulation 2, paragraph 4, provides that ships owned or operated by a contracting State and used only in "Government non-commercial service" are exempted from the regulations. Typically, these are military vessels, including coast guard vessels. Nevertheless, under Regulation 2, paragraph 4, these ships are also "encouraged" to act in a manner consistent with the new safety provisions.

Certain substantive limitations as regards the scope of application of the provisions of the new Chapter must be mentioned. First, according to Regulation 2, paragraph 3, Part I-B of the Code is recommendatory only (the safety measures of the Code are divided into Parts I-A and I-B, with only the rules in Part I-A being binding). Second, Regulation 4 allows "alternative design and arrangements" to those in the Polar Code regarding certain substantive areas. Regulation 4 aims to "provide a methodology for alternative design and arrangements for structure, machinery, and electrical installations, fire safety and life-saving appliances and arrangements." However, if alternative design or arrangements are used, such design and arrangements shall be approved in accordance with Regulation 4, paragraph $3 .{ }^{51}$

\subsection{MARPOL}

While a new and separate chapter of SOLAS will render the safety provisions (in Part I-A) of the Polar Code mandatory, the environmental provisions (in Part II-A) of the Code are to be implemented by amending four different annexes of MARPOL. There will thus not be a separate "Polar Code" chapter of MARPOL. ${ }^{52}$ Amendments to Annex I concern regulations for preventing pollution by oil. Amendments to Annex II consist of regulations for the control of pollution of noxious liquid substances in bulk. Amendments to Annex IV contain regulations for preventing pollution from ship sewage. Finally, amendments to Annex V are on regulations for preventing pollution from ship garbage.

Changes to these annexes have taken the form of rather minor amendments of the wording to various regulations. Some paragraphs have been added or replaced, and existing paragraphs renumbered. Importantly, however, new chapters on scope of application are included in each annex, all titled "International Code for Ships Operating in Polar Waters." In these chapters, the geographical and personal scope of application of the new provisions is determined: the Polar Code and polar waters are defined, and the ships that fall under the regulations are specified. It was deemed necessary to have such a separate chapter in each of the annexes because there is no overarching chapter concerning the scope of application, similar to the new SOLAS "Chapter XIV."

\subsection{Structure and key substantive aspects}

The Polar Code consists of a preamble, an introduction and two main parts. The preamble contains general statements regarding the overarching objectives and 
purpose of the Code. Section 5 calls for safety measures to reduce "the probability of an accident." As States have generally aimed to identify the most risky activities related to polar navigation, section 7 of the preamble provides for a "risk-based approach" to ensure that a "holistic" approach has been utilized to reduce identified risks. The drafters thus seem to recognize that while there may be certain weak points in the Code, as a whole it is regarded as acceptable. This sort of "fallback protection mechanism" is noteworthy - the drafters appear to be seeking to protect themselves from criticism with respect to parts of the Code that are indeed admitted as being too weak.

The following elements are particularly important to note in the Code's "Introduction." Regulation 3.1 contains a list of sources of hazards. Regulation 3.2 introduces a situation-based approach as regards such risks, i.e. that risks vary on the basis of geographical location, the amount of ice-cover, etc. This rule provides a basis for interpreting the Code more strictly in some circumstances. For instance, the term "appropriate survival resources" has different meanings depending on whether it is applied to waters that are entirely ice-covered or waters that are not markedly ice-covered. ${ }^{53}$

\subsubsection{Safety provisions}

The Polar Code's safety measures are contained in Parts I-A and I-B. Regulation 1.1 of the former specifies that each chapter should consist of an "overall goal," "functional requirements to fulfil the goal" and "regulations." In addition to an overarching goal and purpose, each chapter consists of both functional and deterministic regulations. The functional requirements describe, for instance, the qualities of a ship's stability relative to the ship's functionality. ${ }^{54}$ A ship meets a functional requirement when its design and arrangements comply with all the regulations associated with the functional requirement.

Regulations $1-3$ to $1-5$ of Chapter 1 set out three basic requirements for all ships covered by the Code. First, under Regulation 1.3, "every ship" is subject to certain certification provisions. Second, according to Regulation 1.4 there are specific minimum requirements as regards "performance standards": these minimum requirements derive from the standards specified in SOLAS. Third, there is an obligation to conduct an "operational assessment" of a ship's ability to operate in polar waters, also regarding potential risks associated with such navigation. ${ }^{55}$ Taken together, these seem to be appropriate "minimum" requirements that must be met before any ship is allowed to operate in ice-covered waters.

More specific safety measures of the Code are contained in Chapters 2-12. All ships shall carry a polar manual (Chapter 2); there are rules regarding ship structure (Chapter 3); subdivision and stability (Chapter 4); watertightness and watertight integrity (Chapter 5); machinery installations (Chapter 6); fire safety and protection (Chapter 7); life-saving appliances and arrangements (Chapter 8); safety of navigation (Chapter 9); communications (Chapter 10); voyage planning (Chapter 11); and manning and training (Chapter 12). Importantly, according to Regulation 12.3, "adequate" qualifications for crew members will vary from area to area, and 
also depend on the type of ship in question. The strictest qualification requirements apply to tankers and passenger ships.

Extensive references to other instruments is a striking element of the Polar Code. First and foremost, it is interesting to note that private actors have been accorded a role in this legal instrument. Notably, in the provisions regarding ship structure, reference is made to regulations developed by the International Association of Classification Societies (IACS), an organization consisting of 12 global marine classification societies. According to Regulation 3, IACS "Requirements concerning Polar Class" are particularly relevant. ${ }^{56}$ These requirements are also referred to under Regulation 6.3 in connection with machinery installations. Thus, while the Polar Code contains its own categorization of ships intended for polar navigation ("Category A ship," "Category B ship" and "Category C ship"), there are numerous references to standards developed by IACS.

In Regulation 11.3 on requirements for voyage planning, reference is made to certain IMO instruments. Chapter 12 refers to the provisions of the International Convention on Standards of Training, Certification and Watchkeeping for Seafarers (STCW) and the STCW Code. ${ }^{57}$ There are also several references to SOLAS in the Code's provisions on safety measures, as well as in its preamble and general provisions. ${ }^{58}$

Part I-B of the Polar Code - in which the mandatory "shall" has been replaced by "should" throughout - is less comprehensive than Part I-A. However, the recommendatory part contains important additional guidance regarding introduction of the Code and Part I-A, including provisions on ship structure (Regulation 4) and navigation safety (Regulation 10).

\subsubsection{Pollution prevention measures}

The mandatory environmental provisions of the Polar Code are contained in Part II-A, which has chapters on various types of pollution - oil, noxious liquid substances in bulk, garbage, etc. The structure is different compared to the safety part. There are no overarching goals followed by functional and deterministic requirements: the environmental chapters use the term "operational requirements." Chapter 1 on oil pollution also has regulations on "structural requirements." The chapters on prevention of pollution by sewage from ships (Chapter 4) and garbage from ships (Chapter 5) include separate "definitions."

In Arctic waters, any discharges into the sea of oil or oily mixtures from any ship are prohibited. ${ }^{59}$ In addition, any discharge of noxious liquid substances, or mixtures containing such substances, is prohibited in Arctic waters. ${ }^{60}$ The prohibition related to discharge of sewage, however, applies to "polar waters," and includes the Antarctic maritime area. With regard to garbage from ships, Annex V of MARPOL shall apply, but the Polar Code provides for additional and separate regulations with regard to the Arctic $^{61}$ and the Antarctic. ${ }^{62}$

The main impression is of strict regime regarding pollution from oil and noxious liquid substances in bulk. Relevant Annexes of MARPOL are made applicable to sewage (Chapter 4) and garbage (Chapter 5) - Annexes IV and V, respectively. 
The provisions on sewage apply to all polar waters. In making Annex V of MARPOL applicable to pollution from garbage, however, the Polar Code contains stricter and more extensive additional regulations for the Arctic $^{63}$ than for the Antarctic. ${ }^{64}$

In Part II-B of the Polar Code, recommendatory environmental provisions are included. The regulations related to oil pollution are noteworthy, in particular Regulation 1.1, under which ships are "encouraged to apply regulation 43 of MARPOL Annex I when operating in Arctic waters." Regulation 43 provides special requirements for the use or carriage of oil in Antarctic areas.

Regulation 4 should also be noted: until the International Convention for the Control and Management of Ships Ballast Water and Sediments, 2004 (BWM Convention) ${ }^{65}$ enters into force, the provisions of the "Guidelines for ballast water exchange in the Antarctic treaty area" should be taken into consideration along with other relevant guidelines developed by the IMO. ${ }^{66}$

\section{Interplay of vague and substantive rules}

When the work on the Polar Code entered its final phase in 2010, it was emphasized that a goal-based approach should be utilized as a key regulative concept for developing structural design. ${ }^{67}$ Such goal-based design has gained prominence and may even become a general principle in ship design as the methodology used to develop structural standards. ${ }^{68}$ In essence, a regulative approach based on goals places the focus on overall goals rather than prescriptive rules. As such it seeks to replace prescriptive and deterministic regulations with goal-oriented standards.

There are clear expressions of a goal-based approach in the Polar Code, most notably in each chapter of the safety part: they contain prescriptive provisions supported by both overall goals and functional requirements. On the other hand, this legislative technique has also resulted in a striking mix of precise and vague provisions, which are likely to have implications for interpretations of the Polar Code.

The provisions on goals and on functional requirements under each chapter of Part I-A of the Code (for instance rules 7.1 and 7.2, respectively) can be seen both as a context for interpreting the deterministic regulations (rule 7.3), and as rules to ensure an interpretative result based on object and purpose. A purposive or teleological approach to interpretation is clearly in accordance with Article 31(1) of the Vienna Convention on the Law of Treaties. ${ }^{69}$ It means stressing the overarching objectives of each relevant chapter of the Code and putting less emphasis on the wording of the deterministic or technical provisions. Highlighting overall goals and purposive considerations in an interpretation of the Code's descriptive characteristics may give greater room for maneuver for national authorities to fulfill their obligations under the Code; admitting a broad "margin of appreciation" provides certain flexibility and may even permit interference with the prescriptive regulations. Power of discretion, however, does not necessarily imply a lower standard of protection. In the long run, it may also result in stricter standards. ${ }^{70}$

In the context of the Code's provisions on safety measures, the nature of the regulations is a crucial factor in determining how much latitude can actually be 
accorded to national authorities. Not all types of international norms are particularly amenable to a margin of appreciation decision-making methodology. Many of the Polar Code's prescriptive regulations are highly technical and precise, leaving little room for flexibility. Consider Regulation 4.3.1.1. on stability in intact conditions:

In order to comply with the functional requirement of paragraph 4.2 .1 , for ships operating in areas and during periods where ice accretion is likely to occur, the following icing allowance shall be made in the stability calculations:

$130 \mathrm{~kg} / \mathrm{m}^{2}$ on exposed weather decks and gangways;

$27.5 \mathrm{~kg} / \mathrm{m}^{2}$ for the projected lateral area of each side of the ship above the water plane; and

3 the projected lateral area of discontinuous surfaces of rail, sundry booms, spars (except masts) and rigging of ships having no sails and the projected lateral area of other small objects shall be computed by increasing the total projected area of continuous surfaces by $5 \%$ and the static moments of this area by $10 \%$.

Now, is there room for considering object and purpose in an interpretation of such an obligation? There is perhaps no "inherent uncertainty" at all in such norms. ${ }^{71}$ That makes it difficult to see how a State, in interpreting the Code, could possibly lower standards at the domestic level. ${ }^{72}$ Most of the Polar Code's regulations are neither flexible standard-type norms nor very discretionary. The efficacy of utilizing a goal-based approach in developing the Polar Code's provisions is therefore not readily apparent.

\section{Regulatory interplay}

That the Polar Code's provisions are about to become part of SOLAS and MARPOL also prompts discussion on the relationship and interplay of the new regulations with other international shipping regulations. Here we will consider certain legal implications of the Code in relation to the broader context of international law, including legislative arrangements and provisions of the LOS Convention.

\subsection{The Polar Code as external rules of reference under the LOS Convention}

An emergent legal issue is whether the provisions in the Polar Code can be said to be "generally accepted international rules and standards" (GAIRAS) and thereby covered by a relevant rule of reference in the LOS Convention. Instead of providing rules and regulations directly applicable to States Parties, in several instances the LOS Convention functions merely as an umbrella framework, offering only general rules "primarily apportioning competence while leaving technical rules and regulations to the relevant conventions, already existing or still to be created." 73 Importantly, by

becoming a party to the 1982 Convention, states ipso facto accept the legal technique of law-making by reference inherent in the very notion of generally accepted international rules and standards [...] Consequently, flag states, coastal states and port states can enforce concrete international rules and standards which are generally accepted irrespective of the form they have taken [...] This Conclusion does not infringe the pacta tertiis principle, since the consensual nature 
of international law is satisfied by the fact that states, party to the 1982 Convention, did agree to accept the rule of reference. ${ }^{74}$

The considerable extent to which international rules and standards originated outside the LOS Convention is relevant in context of the Convention is a major change compared to how the rules of reference mechanism had been applied under the 1958 High Seas Convention. ${ }^{75}$ A similar procedure was also followed in the 1995 Straddling Fish Stocks Agreement, ${ }^{76}$ under which States Parties agree in advance to be subjected to the regulations enacted by regional fisheries organizations to which a given State may not adhere or whose regulations it may not have consented to. ${ }^{77}$

Basically then, GAIRAS concerns prescriptive and enforcement jurisdiction either of flag States (in which case, it constitutes a mandatory minimum) or of coastal States (where it represents a facultative maximum). For instance, as regards the right of the coastal State to adopt laws and regulations relating to innocent passage under Article 21 of the LOS Convention, paragraph 2 of Article 21 determines that such laws and regulations shall not apply to the "design, construction, manning or equipment" of foreign ships unless they are giving effect to generally accepted international rules or standards. Thus, if a rule or standard is deemed "generally accepted," the exception will apply. Accordingly, the Polar Code will establish an upper limit for the content of national legislation and will serve as a point of reference with regard to which regulations the coastal State has a right to establish for foreign vessels navigating in the territorial sea. Likewise in Article 211, paragraph 2, concerning pollution from vessels: Laws and regulations for the prevention, reduction and control of pollution of the marine environment from vessels flying their flag shall "at least have the same effect as that of generally accepted international rules and standards established through the competent international organization or general diplomatic conference." In such cases, the Polar Code will establish a lower limit for the content of national legislation and provide a point of reference for the regulatory measures a flag State is obliged to establish. Domestic regulations conforming to GAIRAS may also often be enforced by the coastal State (see for instance Article 211, paragraph 5, of the LOS Convention, which provides that coastal States may, for purposes of enforcement, adopt laws and regulations for the prevention, reduction and control of pollution from vessels conforming to and giving effect to GAIRAS).

Are, then, the provisions of the Polar Code "generally accepted international rules and standards?" This question has engendered much theoretical debate. Key points raised are: 1) where should such international rules or standards be developed, 2) to which norms do the concepts apply?, and 3) when does a norm become "generally accepted?"78 Accordingly, this is not only a question about endorsement by States, it is also about qualitative requirements with respect to the regulations in question.

As regards where a generally accepted international rules or standards should be developed, it should be stressed that the Polar Code has been adopted by the organization designated by the LOS Convention as competent with respect to safety 
and environmental aspects regarding vessels. The LOS Convention mentions the IMO explicitly only once, ${ }^{79}$ but generally calls upon the "competent international organization" 80 to develop rules and standards pertaining to navigation safety and environmental protection. Alternatively, such regulations should be developed through "general diplomatic conference." 81 Considering that the LOS Convention elsewhere refers to whichever international organization is competent in the circumstances, indicates that in principle, there may be several organizations that are "competent" with regard to the regulation of shipping. The International Labour Organization (ILO) and the International Atomic Energy Agency (IAEA) also develop international regulations in relation to shipping. That the IMO is the primary competent international organization as regards navigation and related maritime matters is, however, widely accepted ${ }^{82}$ and also follows from the drafters' intentions, as expressed during the Third United Nations Conferences on the Law of the Sea (UNCLOS III). ${ }^{83}$

One complicating factor regarding the Polar Code, however, is that the mandate to adopt regulations in several places has been "delegated" to a private entity: IACS. Although IACS rules are included by reference and not directly incorporated in the Polar Code, its regulations are legally relevant because they are referred to as "acceptable" standards. ${ }^{84}$ As extra-legal norms they may also be important in interpretations of the Code. For example, what is considered an acceptable minimum in terms of ship structure will depend on IACS specifications.

Accordingly, some of the regulations to which the Code refers were not developed by States. Therefore it may be argued that the Code was not wholly developed by "the competent international organization" or at a "general diplomatic conference." The obvious counterargument, however, is that States have accepted the reference to IACS regulations in the Code, and so State consent is present.

With respect to the type of norm to which the concept of GAIRAS can apply, provisions that are incorporated into binding instruments such as SOLAS and MARPOL (the Introduction, Parts I-A and II-A of the Polar Code) will undeniably constitute "rules and standards." To be covered by a relevant rule of reference in the LOS Convention, however, they must also meet certain additional qualitative requirements. For instance, since Article 211, paragraph 5, deals with pollution from vessels, only norms relating to and with the purpose of protecting the marine environment from pollution from vessels will qualify as GAIRAS under that provision. ${ }^{85}$ Likewise, the rule of reference in Article 21, paragraph 2, of the LOS Convention covers safety related provisions.

In context of the Polar Code, however, the first question that arises is whether rules of reference in the LOS Convention also include the recommendatory parts of the Polar Code, i.e. those regulations not incorporated in MARPOL or SOLAS but which remain non-legally binding as IMO resolutions. Distinction in the denotation of the two terms "rules" and "standards" would seem to lie in the capacity of "standards" to cover a wider range of sources. ${ }^{86}$ Yet, while the term does not necessarily point to something that is already binding on subjects, there is doubt as to how far the term can be understood to extend. ${ }^{87}$ 
On the one hand, also the recommendatory parts of the Polar Code were developed by the IMO. Thus their origin can be traced back to States acting through the competent international organization. On the other hand, non-binding instruments do not have any obvious indication of the intent of States to be bound. On the contrary, States may have accepted the recommendatory parts of the Polar Code precisely because of their non-binding nature. The fact that parts of the Code have been singled out as "recommendatory only" is a strong contextual argument that its recommendatory provisions cannot be considered as GAIRAS either. ${ }^{88}$

With regard to the Polar Code, there is a second issue that arises concerning the scope of GAIRAS: Are wholly private undertakings that establish, for instance, construction requirements covered? This question is relevant in the context of the above discussion on IACS regulations. Again, however, the rules of references in the LOS Convention refer back to standards that originate from international organizations and general diplomatic conferences. ${ }^{89}$ This strongly indicates that IACS standards cannot be accepted as GAIRAS, since these regulations were developed beyond the sphere of States and without their input.

Thus far, the conclusion is that all parts of the Polar Code, including IACS regulations, have been endorsed by States through the "appropriate" body for them to qualify as GAIRAS under the LOS Convention. It is argued, however, that the recommendatory parts and IACS regulations do not qualify as "rules and standards" with respect to the GAIRAS-test. For the mandatory elements of the Polar Code (the Introduction, Parts I-A and II-A), which on 1 January 2017 will become part of SOLAS and MARPOL, a final issue to address would be to examine what level of acceptance a source of international law must meet before it can function as an external rule of reference under the LOS Convention. ${ }^{90}$ In other words: will the binding provisions of the Polar Code become "generally accepted" as part of SOLAS and MARPOL?

Various standards have been proposed for assessing whether such acceptance is present. ${ }^{91}$ Does mere adoption suffice for a rule to be "generally accepted?" Is entry into force required? Is even wider acceptance than entry into force required - for instance, so that the threshold for considering rules as "generally accepted" is that they have attained the status of customary international law? ${ }^{92}$

Whether a rule is deemed "generally accepted" must be assessed in terms of the specific instrument at hand. With regard to the provisions of the Polar Code, it could be argued that since the Code has been adopted by (two of the bodies of) the IMO in which the vast majority of the world's States participate - it is sufficient for regulations to be labelled as "generally accepted." However, acceptance of international law should require at least that States actually ratify an instrument, i.e. follow domestic procedures for making international law binding for that particular State. The first level - adoption - is not sufficient.

Entry into force, however, does not necessarily suffice for an instrument to be deemed "generally accepted." Of relevance is what is required for a particular instrument to enter into force: an instrument that requires, say, only five ratifications 
for entry into force cannot be said to be "generally accepted" merely because that number of ratifications has been achieved.

In the case of SOLAS, however, the number of ratifications required for entry into force is of a different kind. We have seen that the new provisions will be deemed to have been accepted on 1 July 2016 unless more than one third of the contracting governments to these conventions, or contracting governments combined merchant fleets of which constitute not less than 50\% of the gross tonnage of the world's merchant fleet, notify objections. ${ }^{93}$ If no objections are raised, the amendments will enter into force on 1 January $2017 .{ }^{94}$ As of 11 February 2016, SOLAS had 162 contracting States, which flag about $99 \%$ of merchant ships around the world in terms of gross tonnage. Thus, it is safe to conclude that these provisions have become "generally accepted" if they enter into force on 1 January 2017.

Likewise, the amendments to MARPOL shall be deemed to have been accepted as of 1 July 2016 unless, prior to that date, not less than one third of the Parties, or the combined merchant fleets constituting not less than $50 \%$ of the gross tonnage of the world's merchant fleet, have communicated objections to the amendments. ${ }^{95}$ Otherwise, the MARPOL amendments will also enter into force on 1 January 2017. Unlike SOLAS, however, the MARPOL amendments are spread across different Annexes, and not all of the Annexes have been ratified by the same number of States. As of 11 February 2016, Annexes I and II had been ratified by 153 States, which flag about $99 \%$ of merchant ships around the world in terms of gross tonnage. Annex IV had been ratified by 136 States (flagging 90.75\%); and Annex V by 148 States (flagging about 98\%). Annex IV represents the lowest number of contracting States/ percentage of world tonnage. However, if more than $90 \%$ of merchant ships around the world in terms of gross tonnage are bound by the regulations, also here it seems safe to conclude that the regulations will be sufficiently endorsed upon entry into force.

Alone, the large number of ratifications/percentage of world tonnage would indicate that the Polar Code provisions in SOLAS and MARPOL are "generally accepted." It could, however, also be argued that true acceptance - or "general acceptance" - of international law will only have taken place after the vast majority of the world's States have taken steps to implement these regulations at the domestic level. Then State behavior and whether States actually live up to their obligations is the decisive element. ${ }^{96}$ In that case, however, it will indeed take some time until the test of general acceptance is fulfilled. States' actual compliance is also a difficult undertaking, and requires detailed examination. At the outset, it should therefore be assumed that States will act in accordance with the obligations that rest on them. ${ }^{97}$ Upon entry into force the Polar Code provisions incorporated in SOLAS and MARPOL will therefore have passed the test of general acceptance, and its provisions will be covered by relevant rules of references in the context of the LOS Convention.

\subsection{Relationship to Article 234 of the LOS Convention}

As regards environmental protection specifically, the LOS Convention contains a special provision relating to coastal State jurisdiction within the limits of the EEZ 
that are partially or completely covered by ice: Article 234. The relationship between Article 234 and the Polar Code provisions has to some extent been addressed through the negotiations process. ${ }^{98}$ However, with the Code's provisions on the way to becoming binding, it is important to clarify the relationship between the new provisions and Article 234.

The primary question is whether Article 234 still has any relevance, or whether this "exception" has become redundant with the finalization and adoption of the environmental measures of the Polar Code, and the attendant changes to SOLAS and MARPOL.

The main point is that a coastal State does not necessarily have to employ Article 234 in setting stricter regulations against pollution within the limits of its EEZ. With the adoption of the Polar Code, it is now likely that States will invoke Article 211, paragraph 5, as the basis for national environmental measures. This is so because Article 211 gives coastal States the right to adopt laws and regulations to prevent, limit and control ship pollution that are in accordance with generally accepted international rules and standards established by the IMO or through general diplomatic conferences. In other words, if the Polar Code's provisions come to be deemed "as conforming to and giving effect to generally accepted international rules and standards established through the competent international organization or general diplomatic conference," the coastal State will be able to use Article 211 as a basis for stricter national measures, with no need to invoke Article 234 of the LOS Convention.

Does this then mean that Article 234 is without legal significance? On no account. It would seem that Article 234 is relevant if a coastal State wants to impose even stricter rules than those in the Polar Code. In contrast to Article 211, Article 234 is not limited to rules adopted by the IMO: what restricts the coastal State in Article 234 is that the provisions shall take due regard of the shipping industry and to the protection and conservation of the marine environment based on the best available scientific material.

Nevertheless, some important issues of interpretation arise. We may ask if adoption of the Polar Code "subsumes" any other international rules pertaining to safety or the environment in polar waters, i.e. that Article 234 also must be limited to IMO regulative efforts - in other words, that LOS Article 234 must be interpreted in light of the subsequent development of and reliance on standards developed by the IMO. ${ }^{99}$

A central reason for concluding that adoption of the Polar Code does not eliminate Article 234 as an alternative basis for adopting stricter environmental (or safety) standards must be that Article 234 does not contain any reference to "generally accepted international rules and standards." Thus, as noted, Article 234 is not limited to rules adopted by the IMO. Nevertheless, the specification in Article 234 that national measures shall take due regard of navigation may limit domestic regulations in accordance with the Polar Code; regulations that go beyond what is required by the Polar Code will hamper those decisions which indeed have been taken by the international community. This would, however, also mean "sidelining" Article 234 and pulling it down to the level of the Polar Code, which does not fit well 
with the wording of the provision, notably that there is no inclusion of "generally accepted international rules and standards." According to Article 234, States shall merely pay "due regard to navigation."

It is not inconceivable that a coastal State, finding some provisions in the Polar Code too weak, may seek to establish stricter requirements pursuant to Article 234 . The Polar Code is clearly not a perfect instrument to ensure sufficient regulation of shipping in ice-covered waters. Despite the fact that the negotiations that resulted in the Code were founded on good science, the provisions represent a political compromise - as is always the case in international law. In a negotiation situation, some provisions end up too weak; Article 234 can work as a safety-net for such cases, and so that it is still possible to increase the level of (safety and) environmental protection with basis in that provision. In light of the wording of Article 234, and the principle of freedom of navigation in the EEZ, it may be necessary for States to justify why an even higher level of protection than the Polar Code is necessary. The key point to emphasize here, however, is that Article 234 still lives its own life as an alternative jurisdictional basis beyond the requirements of the Polar Code.

Support for considering Article 234 as an alternative jurisdictional basis is also found in the two conventions that will soon give binding effect to the Code's provisions, despite the different approaches of SOLAS and MARPOL with regard to how their provisions relate to other rules of international law. MARPOL contains a general provision in its Article 9(2):

Nothing in the present Convention shall prejudice the codification and development of the law of the sea by the United Nations Conference on the Law of the Sea convened pursuant to Resolution 2750C (XXV) of the General Assembly of the United Nations nor the present or future claims and legal views of any State concerning the law of the sea and the nature and extent of coastal and flag State jurisdiction.

SOLAS does not contain such an overall savings clause applicable to the entire Convention. In Chapter XIV, Regulation 2.5, it was therefore necessary to specify: "Nothing in this chapter shall prejudice the rights or obligations of states under international law." While somewhat different in approach, under both SOLAS and MARPOL it is still so that implementation of the Polar Code's provisions is not to affect the rights and obligations that States have under other international law instruments. Article 234, as part of the LOS Convention, obviously falls in this category, and provides a basis for designating waters within the limits of the EEZ as a "special area" where stricter rules can be invoked. It is not known whether any States Parties have reached agreement to modify or suspend operation of Article 234 in accordance with Article 311, paragraph 3 of the LOS Convention.

\section{Conclusions}

The adoption of the Polar Code, with attendant amendments to MARPOL and SOLAS, marks the end of nearly 25 years of IMO-work focusing on international 


\section{Ø. Fensen}

maritime regulation for polar shipping. It has become essential to have special rules for this purpose, as navigation in the Polar Regions is expected to increase in the years to come. The effectiveness of the new rules has been secured by making the new regulations part of maritime conventions, with close to global support.

As is common with international law, the rules of the Polar Code are the result of negotiated compromises. A pertinent question is therefore whether all of the rules are sufficiently stringent. In addition, the Code and its provisions entail several implications and challenges that are relevant to the broader context of international law.

One important aspect relates to treaty interpretation. How shall treaty obligations that are partly very technical and partly consist of provisions that focus on object and purpose, be interpreted? Some chapters in the Polar Code contain both general and detailed substantive rules. Technical prescriptions are, however, difficult to interpret in any other way than in accordance with the ordinary meaning of the words used. It can thus be questioned how successful the goal-based legislative technique used by the Code has, in fact, been. Provisions on object and purpose will make considerable sense where related provisions open up for different interpretive options. However, in situations where the regulations are very precise, overall goal-based regulations may prove redundant.

Another implication is the GAIRAS-test - that is, whether or not the Polar Code, or any of its provisions, can be said to form part of the extended normative framework of the LOS Convention in terms of shipping regulations. It has been argued that the mandatory requirements of the Polar Code - those regulations incorporated into SOLAS and MARPOL - will be considered as GAIRAS when the relevant amendments enter into force on 1 January 2017. With respect to the nonbinding parts of the Polar Code, however, these should not be considered "rules and standards" under the GAIRAS-test: a decisive factor is that States may have accepted the recommendatory parts of the Polar Code precisely because of their nonbinding nature. Moreover, IACS standards are likely to fail to qualify as GAIRAS since these regulations - despite being subject to State consent - were developed beyond the sphere of States and without their input.

A third implication relates to the interplay between the Polar Code and Article 234 of the LOS Convention. It has been argued that the new provisions of MARPOL and SOLAS will not impinge on the opportunities that a coastal State has to invoke Article 234. Article 234 is still an alternative basis for adopting stricter rules for icecovered parts of the EEZ. It may be argued, however, that the criterion "due regard to navigation" - as stated in Article 234 - must be understood in light of the provisions of the Polar Code. This may imply that Article 234 needs to be interpreted in light of regulative efforts taken by the IMO. Concluding that the Polar Code is the normative "maximum," however, does not stand well with the basic fact that Article 234 is in force and that it contains no explicit reference to rules developed by the IMO. 


\section{NOTES}

1. IMO Doc. MSC.385(94).

2. $\quad$ IMO Doc. MSC 94/21/Add.1., Annex 6.

3. Published in United Nations Treaty Series, 1184, p. 2.

4. Reprinted in International Legal Materials, 12, 1973, pp. 1,319ff (Convention) and International Legal Materials, 17, 1978, pp. 546ff (Protocol).

5. Published in United Nations Treaty Series, 1833, p. 3.

6. IMO Doc. MSC 59/30/32.

7. Jensen, Øystein. "Arctic Shipping Guidelines: Towards a Legal Regime for Navigation Safety and Environmental Protection." Polar Record 44 (2008): 107-14.

8. Code in IMO Doc. DE 41/WP.7, Annex 1. See also IMO Doc. DE 41/10, Annex 1.

9. Ibid., 3.

10. IMO Doc. DE $42 / 14 / 1$.

11. IMO Doc. DE 43/12.

12. Ibid.

13. Ibid., attachment.

14. Part 1 in IMO Doc. DE 43/WP.10. Part 2 in IMO Doc. DE 44/12, Annex 2. See also IMO Doc. DE 44/WP.2.

15. IMO Doc. SLF 44/8.

16. IMO Doc. MEPC 48/21.

17. IMO Doc. MSC/Circ.1056-MEPC/Circ.399.

18. See IMO Docs. MSC 79/8/2 and MSC 79/INF.2.

19. See Decision 4, in Final Report of ATCM XXVII, p. 189.

20. IMO Doc. MSC 79/23.

21. IMO Doc. DE 52/INF.4.

22. IMO Doc. DE 52/9/2., paras 3-5.

23. IMO Doc. DE 52/21.

24. Ibid.

25. IMO Doc. DE 52/21, para. 9.9.

26. IMO Doc. MSC 86/26.

27. IMO Doc. MEPC 59/24.

28. IMO Doc. MSC 86/23/9.

29. IMO Doc. MSC 86/26, paras. 23.32-23.34.

30. IMO Doc. MSC 86/26, para. 23.32.

31. IMO Doc. DE 56/25, para. 10.8 .

32. IMO Doc. MEPC 62/11/4/Add.1.

33. Ibid., para. 4.

34. IMO Doc. MEPC 63/23, paras. 11.9-11.18.

35. IMO Doc. MSC 91/22, para. 8 .

36. IMO Doc. $57 / 25$, para. 11.40 .

37. Ibid., para. 11.39.

38. Ibid., para. 11.10.

39. IMO Doc. SDC $1 / 26$, para. 3.67.

40. Ibid., Annex 3.

41. Ibid., para. 26.1.

42. Ibid., para. 26.2.

43. Res. MSC.385(94). See also IMO Doc. MSC 94/21.

44. Res. MSC.386(94). 
45. Res. MEPC.264(68).

46. Res. MEPC.265(68).

47. Res. MSC.386(94), no. 3.

48. Res. MEPC.265(68), para. 3.

49. Regulation 1, litra a, of Chapter I, Part A, of SOLAS.

50. Ibid., Regulation 2, litra d.

51. Which in turn refers to Guidelines for the Approval of Alternatives and Equivalents as Provided for in Various IMO Instruments (IMO Doc. MSC.1/Circ.1455), Guidelines on Alternative Design and Arrangements for SOLAS Chapters II-1 and III (IMO Doc. MSC.1/ Circ.1212) and Guidelines on Alternative Design and Arrangements for Fire Safety (IMO Doc. MSC/Circ.1002), as applicable.

52. Res. MEPC.265(68).

53. Regulation 8.3.3.3. (sub-para. 2).

54. Chapter 4, Part I-A.

55. Regulation 1.5., Part I-A.

56. Throughout the entire negotiation process, classification societies played an important role, specifically through the establishment of "ice classes" assigned to a ship on the basis of its operational capability and strength of construction. In August 2006, the work of IACS on ice classes culminated in the release of "Unified Requirements for Polar Ships," standardizing global ice classification specifications. Seven "polar classes" were established, under which Polar Class 1 relates to ships in year-round operation in all polar waters, whereas Polar Class 7 relates to ships engaged in summer/autumn operation in thin first-year ice which may include old ice inclusions. Regulations, http://www.iacs.org.uk (accessed March 10, 2016).

57. Adopted in London on 7 July 1978; entered into force 28 April 1984. Published in United Nations Treaty Series, 1361, p. 190. The Convention incorporates the 2010 Manila Amendments to the Annex, which were adopted in Manilla 25 June 2010 and entered into force 1 January 2012.

58. Regulations 4.3.2.1 and 9.3.2.1.

59. Regulation 1.1.1., Part II-A.

60. Regulation 2.1.1., Part II-A.

61. Regulation 5.2.1, Part II-A.

62. Regulation 5.2.2., Part II-A.

63. Regulation 5.2.1., Part II-A.

64. Regulation 5.2.2., Part II-A.

65. Adopted in London on 13 February 2004; not yet in force. Text in IMO Doc. BWM/ $\mathrm{CONF} / 36$.

66. IMO Doc. MEPC.163(56).

67. IMO Doc. DE 54/WP.3, p. 5.

68. See Hamann, Rainer, and Jörg Peschmann, "Goal-Based Standards and Risk-Based Design." Ship Technology Research 60 (2013): 46-56; and Papanikolaou, Apostolos ed. Risk-Based Ship Design - Methods, Tools and Applications. Berlin: Springer-Verlag, 2009. See also IMO Doc. MSC 80/6/6.

69. Adopted on 22 May 1969; entered into force 27 January 1980. Text in United Nations Treaty Series, 1155, p. 331.

70. Fauchald, Ole Kristian, "Regulatory Frameworks for Maritime Transport in the Arctic," Marine Transport in the High North. Oslo: Det Norske Videnskaps-Akademi/Norges Tekniske Vitenskapsakademi, 2011, 82.

71. Shany, Yuval. "Toward a General Margin of Appreciation Doctrine in International Law?" European fournal of International Law 16 (2005): 907-40. 
72. As there is nothing in SOLAS, MARPOL and the LOS Convention to prevent States - in their capacity as flag States - from imposing more stringent standards on their vessels, the same cannot be said about a higher level of stringency.

73. See "Report of the London Conference" (2000) drafted by the Committee on Coastal State Jurisdiction Relating to Marine Pollution of the International Law Association (ILA), p. 32, http://www.ila-hq.org/ (accessed March 10, 2016).

74. Ibid., 45-6.

75. Skodvin, Knut Einar. Freedom of Navigation in the Exclusive Economic Zone under the LOS Convention: Balancing Coastal and Maritime State Interests. Bergen: University of Bergen, 2013, 361

76. Agreement for the Implementation of the Provisions of the Convention Relating to the Conservation and Management of Straddling Fish Stocks and Highly Migratory Fish Stocks. See UN Doc. A/CONF.164/37.

77. Supra note 73, p. 50 .

78. Johnson, Lindy S. Coastal State Regulation of International Shipping. Dobbs Ferry, NY: Oceana, 2004, 74 .

79. See Article 2, para. 2, of Annex VIII.

80. As particularly related to shipping, see Article 22, para. 3 (a), Article 41, paras. 4 and 5, Article 53, para. 9, Article 60, paras. 3 and 5, Article 211, paras. 1, 2, 3 and 5 (a), Article 217, paras. 1, 4 and 7, Article 218, para. 1 and Article 220, para. 7, of the LOS Convention.

81. As particularly related to shipping, see Article 211, paras. 1, 2 and 5, Article 217, paras. 1 and 4 and Article 218, para. 1, of the LOS Convention.

82. Molenaar, Erik. Coastal State Furisdiction Over Vessel-Source Pollution. Utrecht: G.J. Wiarda Instituut, 1998, 136.

83. See Nordquist, Myron H., ed., United Nations Convention on the Law of the Sea 1982: A Commentary, 4, Dordrecht: Martinus Nijhoff, 1985, 15.

84. For instance, Regulation 3.3.2 provides that the collective dimensions of the various parts of category A and B ships ("scantlings") shall be approved by taking into account "standards acceptable to the [IMO]." By footnote, reference is explicitly made to IACS' Unified Requirements concerning Polar Class. Likewise for the provisions on machinery installations in Chapter 6 of the safety regulations, where Regulation 6.3.2 stipulates that, in approving materials of exposed machinery and foundations, account shall be taken of standards acceptable to the IMO. Explicit reference, by footnote, is made to IACS' Unified Requirements.

85. Depending also, of course, of whether the criterion "generally accepted" is fulfilled.

86. Skodvin, supra note 75,364 .

87. Churchill, Robin R., and Alan Vaughan Lowe, The Law of the Sea. Manchester: Manchester University Press, 1999, 347.

88. For the view that rules and standards are restricted to those laid down in instruments intended to be binding, see, for instance, Boyle, Alan. "Marine Pollution under the Law of the Sea Convention." American Fournal of International Law 79 (1985): 347-72, at 357.

89. While the wording in Article 211, paragraph 5, of the LOS Convention explicitly refers to "the competent international organization" or "general diplomatic conference," no such positive reference is made in Article 21, paragraph 2, concerning rules on design, construction, manning or equipment.

90. Skodvin, supra note 75, p. 362.

91. Ibid., $377 \mathrm{ff}$.

92. See generally Molenaar, supra note 82 , pp. 152-7.

93. Res. MSC.385(94), para. 2.

94. Res. MSC.386(94). 
Ø. Fensen

95. Res. MEPC.265(68).

96. Oxman, Bernard H. "The Duty to Respect Generally Accepted International Standards." New York University fournal of International Law and Politics 24 (1991): 109-59

97. Skodvin, supra note 75, p. 383.

98. See generally McDorman, Ted. "A Note on the Potential Conflicting Treaty Rights and Obligations between the IMO's Polar Code and Article 234 of the Law of the Sea Convention." In International Law and Politics of the Arctic Ocean: Essays in Honor of Donat Pharand, eds. Suzanne Lalonde, and Ted L. McDorman, 141-159. Leiden/Boston: Brill/ Nijhoff, 2015.

99. Fauchald, supra note 70, p. 83. 